\title{
PREDICTION OF THE DEVELOPMENT OF RETINAL MORPHOLOGICAL CHANGES AFTER PHACOEMULSIFICATION BASED ON THE STATE OF THE CYTOKINE PROFILE OF INTRAOCULAR FLUID
}

DOI: 10.36740/WLek202004133

\author{
Iryna M. Bezkorovayna, Iryna S. Steblovska, Vita V. Ryadnova, Anna V. Pera-Vasilchenko, \\ Liudmyla K. Voskresenska, Nina M. Bezega \\ UKRAINIAN MEDICAL STOMATOLOGICAL ACADEMY, POLTAVA, UKRAINE
}

\begin{abstract}
The aim: To investigate the features of cytokine profile of intraocular fluid in patients undergoing cataract phacoemulsification and the effect of their level on the nature and frequency of early and late postoperative complications from the retina.

Materials and methods: The work involved 82 patients ( 82 eyes) with cataract during traditional phacoemulsification on the basis of Ophthalmology department of Poltava Regional Clinical Hospital. The intraocular fluid for the study, while performing phacoemulsification of the nucleus, was collected with a single insulin syringe through the paracentesis of the cornea in the volume of $0.3-0.4 \mathrm{ml}$ for the examination of TNF- $a$ and bFGF levels.

Results: It was found that the level of TNF-a intraocular fluid ranged from $1.11 \mathrm{pg} / \mathrm{ml}$ to $140.55 \mathrm{pg} / \mathrm{ml}$; its average was $24.61 \pm 5.43 \mathrm{pg} / \mathrm{ml}$. When examining the level of bFGF in intraocular fluid, it ranged from $1.0 \mathrm{pg} / \mathrm{ml}$ to $12.54 \mathrm{pg} / \mathrm{ml}$; its average was $3.33 \pm 0.44 \mathrm{pg} / \mathrm{ml}$.

Conclusions: Comparing the levels of the effect of TNF-a and bFGF of the intraocular fluid of patients with cataracts and morphological changes of the retina after phacoemulsification revealed a direct dependence of the level of these factors on the development of macular edema.
\end{abstract}

KEY WORDS: cataract, macular edema, cataract phacoemulsification, cytokine

\section{INTRODUCTION}

Despite the constant development and improvement of cataract surgery techniques, macular edema (ME) continues to be an important cause of decreased postoperative vision [1]. The occurrence of edema of the central area of the retina after cataract surgery was first described by Irvine in 1953, and to this day this condition is described in the literature as Irvine-Gass syndrome [2].

The exact mechanisms underlying the pathogenesis of $\mathrm{ME}$ after cataract surgery have not been elucidated, but the influence of inflammatory mediators on the morphological changes of the central retina has been discussed, namely certain types of interleukins and prostaglandins, whose level increases after surgery [3].

\section{THE AIM}

To investigate the features of cytokine profile (TNF- $\alpha$ and bFGF level) of intraocular fluid in patients with cataract during cataract phacoemulsification and the effect of their level on the nature and frequency of early and late postoperative complications from the retina.

\section{MATERIALS AND METHODS}

The study of the presence and level of cytokines was performed in 82 patients ( 82 eyes) with cataract during traditional phacoemulsification. The intraocular fluid for the study was selected using an insulin syringe trough the corneal paracentesis. Immediately after removal, the moisture was transferred to a test tube for use in a $10 \mathrm{ml}$ centrifuge and cooled. The intraocular fluid was stored in Eppendorftubes - $1.5 \mathrm{ml}$, at a temperature of about -70 ${ }^{\circ} \mathrm{C}$ for 3-4 weeks. Quantitative indicators of TNF- $\alpha$ and bFGF were determined by enzyme-linked immunosorbent assay using standard reagent kits. All studies were performed following the instructions attached to the reagent kit by the manufacturer. Statistical processing of the results was performed on a personal computer using STATISTICA and Microsoft Excel.

The Mann-Whitney criterion was determined while comparing the averages in the two independent groups.

The Kruskal-Wallis $\mathrm{H}$-criterion was determined for significance of differences in the mean values of the studied characteristics.

\section{RESULTS AND DISCUSSION}

In determining the TNF- $\alpha$ indices of the chamber fluid, it was found that it ranged from $1.11 \mathrm{pg} / \mathrm{ml}$ to 140.55 


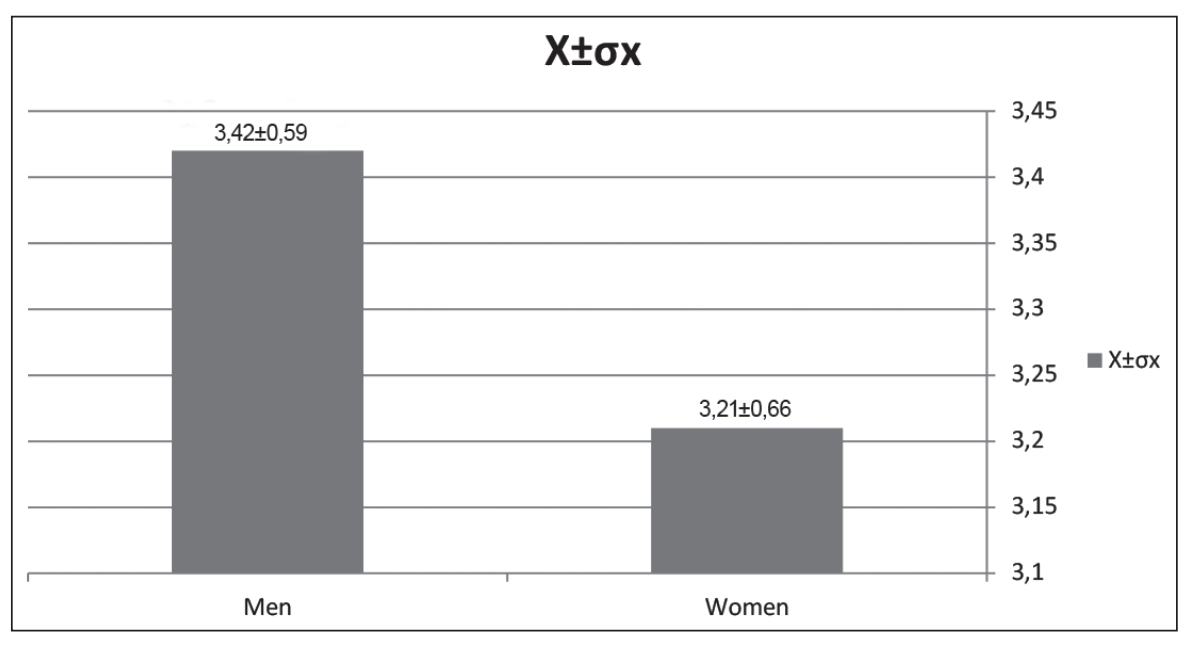

Fig. 1. The value of the Kruskal-Wallis test

Table I. Dependence of TNFa level of intraocular fluid of cataract patients after phacoemulsification on the degree of Buratto lens nucleus density

\begin{tabular}{ccc}
\hline $\begin{array}{c}\text { The degree of density of the nucleus } \\
\text { of the lens by Buratto }\end{array}$ & TNF- $\boldsymbol{a} \pm \boldsymbol{\sigma x}$ & Kruskal-Wallis test \\
\hline I & $30,2 \pm 8,2$ & $\begin{array}{c}\mathrm{H}=3,17 \\
\mathrm{p}=0,35\end{array}$ \\
\hline II & $23,4 \pm 10,69$ & $\mathrm{H}$ \\
\hline
\end{tabular}

$\mathrm{pg} / \mathrm{ml}$; its average was $24.61 \pm 5.43 \mathrm{pg} / \mathrm{ml}$. Studies have shown that the level of TNF- $\alpha$ in the intraocular fluid of cataract patients after cataract phacoemulsification was independent of the sex of the subjects. The Kruskal-Wallis definition and its values were $\mathrm{H}=0.25, \mathrm{p}=$ 0.62 . TNF- $\alpha \mathrm{X}^{-} \pm \sigma \mathrm{x}$ for men $-25.04 \pm 7.07$, for women $24.12 \pm 8.57$. A slight increase in intraocular fluid TNF- $\alpha$ was found in men, but this increase was not statistically significant.

We found that the levels of TNF- $\alpha$ in the intraocular fluid did not correlate with the age of the patients studied. The value of the Kruskal-Wallis test and the level of significance of the test was $\mathrm{H}=3.34, \mathrm{p}=0.34$. In the group of patients 40-49 years, the value of $\mathrm{X}^{-} \pm \sigma \mathrm{x}$ (TNF- $\alpha$ ) was $38.7 \pm 15.187$, at the age of $50-59$ years $-12.4 \pm 4.3$, in the older age group 60-69 years $-28,7 \pm 11.3$ and $19.4 \pm 10.9$ at age 70 and above.

Also, we did not find any relation of TNF- $\alpha$ level in the intraocular fluid on the degree of Buratto lens core density was. This reflects the table I.

When determining bFGF of the intraocular fluid, it was in the range from $1.0 \mathrm{pg} / \mathrm{ml}$ to $12.54 \mathrm{pg} / \mathrm{ml}$; its average was $3.33 \pm 0.44 \mathrm{pg} / \mathrm{ml}$. Our studies have found that the level of bFGF intra-ventricular fluid in patients after the extraction of the mature lens isn't dependent on sex. The value of the Kruskal-Wallis test and its significance level was $\mathrm{H}=0.34, \mathrm{p}=0.56 . \mathrm{X}^{-} \pm \sigma \mathrm{x}(\mathrm{bFGF})$ for men was $3.42 \pm$ 0.59 , for women $-3.21 \pm 0.66$ (Figure 1 ).

It was also found that the level of bFGF of the intraocular fluid wasn't dependent on the age of the cataract

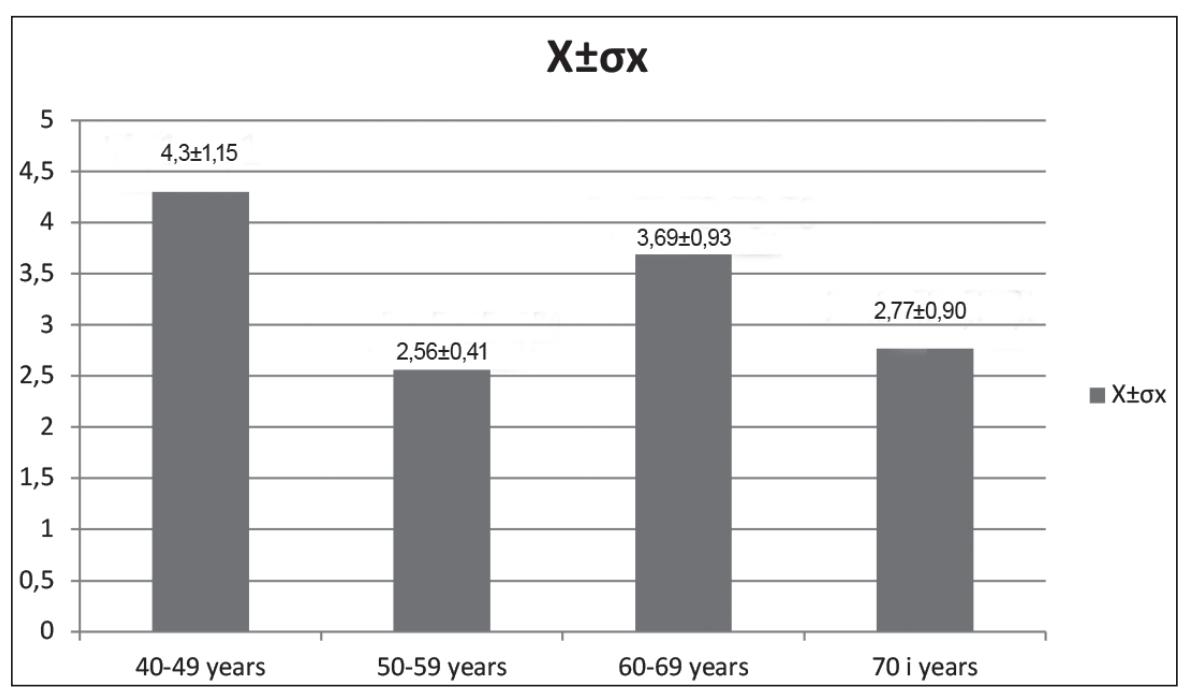

Fig. 2. Dependence of the level of bFGF of the intraocular fluid with the age of the cataract patients after cataract extraction 
Table II. The dependence of the frequency of macular edema at different examination times on the level of TNF- $a$ in the intraocular fluid in patients with cataract after phacoemulsification

\begin{tabular}{|c|c|c|c|}
\hline Number of patients & $\begin{array}{l}\text { The incidence } \\
\text { of retinal edema at the } \\
1 \text { st day after surgical } \\
\text { treatment } \\
(\%, P \pm \mathrm{m})\end{array}$ & $\begin{array}{l}\text { The frequency } \\
\text { of development of retinal } \\
\text { edema in a } 1 \text { month } \\
\text { after surgery } \\
(\%, P \pm \mathrm{m})\end{array}$ & $\begin{array}{l}\text { The frequency } \\
\text { of edema of the retina } \\
\text { in } 1 \text { year } \\
\text { after removal } \\
(\%, P \pm \mathrm{m})\end{array}$ \\
\hline 1. Total $(n=82)$ & 4,8 & 7,3 & 3,6 \\
\hline $\begin{array}{l}\text { 2. Patients with TNF-a level } \\
\text { of intraocular fluid } 36.3 \mathrm{pg} / \mathrm{ml} \\
\text { and above }(\mathrm{n}=6)\end{array}$ & 66,7 & 100 & 50 \\
\hline $\begin{array}{l}\text { 3. Patients with TNF-a intraocular } \\
\text { fluid } 20.0 \mathrm{pg} / \mathrm{ml} \text { and below }(\mathrm{n}=76)\end{array}$ & - & - & - \\
\hline $\mathrm{p}_{2-3}$ & $<0,01$ & $<0,05$ & \\
\hline
\end{tabular}

Table III. The average thickness of the central area of the retina, depending on the level of bFGF of the intraocular fluid

\begin{tabular}{cc}
\hline The average retinal thickness of the macular area $(\boldsymbol{\mu m})$ & The level of bFGF of the intraocular fluid (PCG / $\mathbf{m l})$ \\
\hline $150-200$ & $1-3,01$ \\
\hline $201-300$ & $3,1-6,03$ \\
\hline $301-400$ & $6,77-12,54$ \\
\hline
\end{tabular}

patients after cataract extraction, as can be seen from Figure 2.

When comparing the levels of study of the effect of TNF- $\alpha$ and bFGF intraocular fluid of patients with cataract and morphological changes of the retina after phacoemulsification, we determined the dependence on the level of these factors on the development of macular edema. This dependency is reflected in Table II.

The table III presents the average thickness of the retina in the macular area, depending on the level of bFGF intraocular fluid.

During the course of the studies, a direct correlation was established between the index of the average retinal thickness in the macular area and the level of bFGF in the intraocular fluid (Spearman coefficient $r=0.74 ; p<0.05$ ).

Our immunological studies have once again confirmed the presence of local immune disorders of the visual organ in patients with cataract. Also during the course of observations we first established the fact of a strong direct correlation between the levels of TNF- $\alpha$ and bFGF in the intraocular fluid, as well as their effect on the frequency of edema of the central retinal area and indicators of the average retinal thickness.

Thus, our studies have found that in patients with cataract after phacoemulsification, the level of TNF- $\alpha$ factor is subject to significant fluctuations and isn't dependent on the sex and age of the patients, as well as the degree of Buratto lens nucleus density.

In the study of the effect of TNF- $\alpha$ and bFGF of the intraocular fluid of patients with cataract on the incidence of macular edema at different times after surgery, it was found that the anti-inflammatory cytokine TNF- $\alpha$ has imfluence at the development of macular edema in the early and distant periods after cataract removal, the level correlates with the frequency of this complication.

\section{CONCLUSIONS}

As a result of the conducted researches it was found:

1. The higher the level of TNF- $\alpha$ in the intraocular fluid of patients with cataract after phacoemulsification, the greater the possibility of macular edema.

2. The higher the level of bFGF in the intraocular fluid of patients with cataract after phacoemulsification, the higher the average retinal thickness in the macular area.

3. At thelevel of TNF- $\alpha$ in intraocular fluid above $36.36 \mathrm{pg} / \mathrm{ml}$ macular edema develops in $66,67 \%, 100 \%$ and $50 \%$ of cases in the 1st day, 1 month and 1 year, respectively.

4. The levels of TNF- $\alpha$ and bFGF have effect on the morphometric parameters of the retinal macular area after cataract extraction.

\section{REFERENCES}

1. Forouhe Z., Fatemeh A., Nazanin M. Interleukin-6 participation in pathology of ocular diseases. Pathophysiology. 2017;3:123-131

2. Fadyeyeva T. Kliniko-funktsionalnyie rezultatyi fakoemulsifikatsii s implantatsiey intraokulyarnoy linzyi u patsientov $s$ rannimi formami vozrastnoy makulyarnoy degeneratsii [Clinico-functional results of phacoemulsification with implantation of an intraocular lens in patients with early forms of age-related macular degeneration]spets. 14.00.08 «Oftalmolohia» (In Russian).

3. Ning D., Bing X., Bingsong W et al. Aqueous Cytokines as Predictors of Macular Edema in Patients with Diabetes following Uncomplicated Phacoemulsification Cataract Surgery. 2015.doi: 10.1155/2015/126984

4. Bezkorovaina I.M., Steblovska I.S. Assessing the efficacy of surgical treatment for age-related cataract through risk factor analysis. J. ophthalmol. 2018; 1:3-6.

The research was done as a part of scientific work "Clinical morphological changes of eye structures in degenerative diseases of the organ of vision". State registration № 01144001456. 


\section{ORCID and contributionship:}

Iryna M. Bezkorovayna - 0000-0001-9175-2993 ${ }^{F}$

Iryna S. Steblovska - 0000-0002-9151-2524 $4^{B, D}$

Vita V. Ryadnova - 0000-0001-8815-7827 ${ }^{\mathrm{E}}$

Anna V. Pera-Vasilchenko - 0000-0003-0923-8552 ${ }^{A}$

Liudmyla K. Voskresenska - 0000-0001-6389-8928 ${ }^{\mathrm{E}}$

Nina M. Bezega - 0000-0001-9707-8741 ${ }^{\mathrm{C}}$

\section{Conflicts of interest:}

Authors declare no conflict of interest.

\section{CORRESPONDING AUTHOR}

Iryna S. Steblovska

Ukrainian medical stomatological academy

Shevchenka st, 23, 36011, Poltava, Ukraine

tel: +380666871079

e-mail: oftal.kafedra_poltav@emaol.ua

Received: 01.07.2019

Accepted: 28.01 .2020

A - Work concept and design, B - Data collection and analysis, C - Responsibility for statistical analysis,

D-Writing the article, $\mathbf{E}$-Critical review, $\mathbf{F}$ - Final approval of the article 